SILVA, Vagner Gonçalves da (org.). Intolerância Religiosa: impactos do neopentecostalismo no campo religioso afro-brasileiro. São Paulo: Editora da Universidade de São Paulo, 2007, 328pp.

\title{
Os Rumos da Intolerância Religiosa no Brasil
}

Janayna de Alencar Lui

A chamada teologia da batalha espiritual tomou força nas duas últimas décadas, junto com o crescimento do universo evangélico que inclui hoje forte poder midiático e político. Essa expansão evangélica no Brasil também fez eclodir atos de intolerância religiosa praticados contra as religiões afro-brasileiras, principalmente partindo de neopentecostais. Desde que o fundador da Igreja Universal do Reino de Deus (IURD), o bispo Edir Macedo, declarou guerra aos "orixás, caboclos e guias" numa clara alusão aos elementos dos rituais do candomblé, da umbanda e do espiritismo, jornais, revistas e a mídia em geral têm noticiado os constantes ataques sofridos pelas religiões de matriz africana. 0 demônio iurdiano leva o nome de "exu", "pomba-gira", "encosto", ou seja, para esses neopentecostais tudo que se refere às religiões afro-brasileiras é contagioso; é obra do diabo e deve ser evitado por aqueles que optaram por "aceitar Jesus".

Essa coletânea organizada por Vagner Gonçalves da Silva trata justamente desta temática: os efeitos do neopentecostalismo no campo religioso afro-brasileiro. São oito artigos cuja abordagem dá ênfase às questões sobre a intolerância religiosa, através da análise de eventos polêmicos sobre ações neopentecostais, tais como o tão noticiado "chute na santa" praticado por um pastor neopentecostal contra uma imagem de Nossa Senhora A parecida e a aprovação da lei de proteção aos animais no Rio Grande do Sul, que restringia o sacrifício de animais nos rituais das religiões de matriz africana.

0 artigo de A ri Pedro Oro abre a coletânea e aborda as reações afro no Rio Grande do Sul contra os atos de intolerância praticados por iurdianos. 0 autor mostra que os ataques desses neopentecostais são mais fortes do que as reações de suas vítimas, ou seja, a resposta dos membros de cultos afro-brasileiros ainda é muito branda diante das ações de intolerância por eles sofrida. O ro enfatiza três aspectos característicos da IURD: seu caráter "religiográfico", "exacerbatório" e "macumbeiro". Religiográfico porque "construiu seu repertório simbólico, suas crenças e ritualísticas incorporando e ressemantizando elementos 
de outras religiões" (:33); exacerbatório pelo montante de publicações, programas de TV, templos suntuosos e todo um império que constituiu hoje a IURD no Brasil e no exterior; e macumbeiro porque empresta termos das religiões afrobrasileiras ("trabalho", "encosto", "carrego", "descarrego" etc.) e os ressemantiza para sustentar seu discurso.

A lejandro Frigerio faz um mapeamento das disputas entre neopentecostais e evangélicos no Uruguai e na A rgentina num quadro histórico comparativo. A ponta a importância da análise dos conflitos entre esses dois grupos religiosos e sugere que sua gênese está relacionada aos níveis de legitimidade e visibilidade social alcançados por cada um deles em cada sociedade. Frigerio enfatiza, com base em análise desenvolvida no estudo de movimentos sociais, que os líderes religiosos preocupados com a legitimação social da religião devem desenvolver "marcos interpretativos coletivos" que impulsionem a construção de "identidades coletivas mobilizadas para a ação" e para isso devem mobilizar "recursos econômicos e culturais" no interior e no exterior de sua religião, assim como aproveitar a "estrutura de oportunidades" do meio social no qual se desenvolvem $(: 73)$.

A o tratar dos "Pentecostais em ação", Ricardo Mariano destaca as razões do combate pentecostal aos cultos afro-brasileiros, sendo este combate sua principal estratégia de evangelização. Para Mariano, as principais razões e justificativas pentecostais são "a perspectiva dualista, a interpretação bíblica e a defesa contumaz do resgate da difusão de crenças e práticas do cristianismo primitivo" (:129), tudo isso voltado para "disseminar a crença na ação e no poder maléficos do diabo e dos demônios sobre a humanidade; realizar rituais exorcistas; evangelizar tendo como foco a missão concomitantemente conversionista e salvacionista e de combate às forças demoníacas e a seus agentes e representantes terrenos" (:130). Mariano discute ainda, de forma sucinta, conceitos sobre tolerância, intolerância, discriminação e liberdade religiosa.

A análise de Emerson Giumbelli recai sobre a qualificação da vitimização dos afro-brasileiros, e nos faz refletir sobre as configurações e as articulações entre o campo religioso e a sociedade no Brasil. Giumbelli toma como ponto de partida um material encontrado através de pesquisas no Centro de Referência contra a Discriminação Religiosa (CRDR) no Rio de Janeiro, órgão vinculado ao executivo estadual cujo objetivo é prestar serviços relativos à assistência jurídica em casos de conflitos religiosos. 0 autor reflete criticamente sobre a categoria "fundamentalismo" como referência para pensar a intervenção da religião sobre a sociedade, tomando como exemplos a Índia, os Estados Unidos e o Brasil.

Em "Dez anos do chute na santa - a intolerância com a diferença", Ronaldo Almeida retoma a análise do episódio ocorrido em 1995, transmitido pela Rede Record de Televisão, durante um programa religioso no qual um 
pastor da Igreja Universal do Reio de Deus chutou a imagem de Nossa Senhora A parecida justamente no dia de sua comemoração (12 de outubro). A cena foi retransmitida durante o Jornal $\mathrm{Nacional}$ da Rede Globo, o que intensificou 0 conflito com a Igreja Católica. A Imeida analisa ainda, a relação da Igreja Universal com as outras religiões e prescreve que a forma de lidar com a diferença pode levar "às vias da intolerância dos ritos nas idéias e nas relações sociais face a face" (:187).

0 argumento utilizado por Vagner Gonçalves da Silva segue uma linha comparativa dos termos utilizados pelo neopentecostalismo, catolicismo e pelas religiões afro-brasileiras através da análise da relação socioestrutural existente entre esses campos religiosos. Silva vai buscar inspiração em autores clássicos da antropologia tais como Lévi-Strauss e Marcel Mauss, chegando a uma interessante análise sobre a eficácia simbólica do universo neopentecostal.

$\mathrm{M}$ arcelo $\mathrm{N}$ atividade e Leandro de Oliveira analisam como diferentes religiões (pentecostais, católica e afro-brasileiras) reagem às práticas homossexuais de seus adeptos. O s neopentecostais têm definido a homossexualidade como um desvio de conduta que pode ser revertido com a conversão, transformando-os em "ex-homossexuais" (:262). A lém disso, trazem ao debate o posicionamento oficial da Igreja Católica e seu conservadorismo diante do tema. Por outro lado, os afro-brasileiros são mais flexíveis diante da homossexualidade. Os autores fazem, ainda, uma revisão das pesquisas em ciências sociais e analisam discursos pastorais cristãos sobre as estratégias de regulação da sexualidade presentes nessas religiosidades e os discursos produtores da homofobia.

Fechando a coletânea, 0 artigo de Hédio Silva Jr., único jurista dentre os autores, faz menção ao caráter legal da intolerância, trazendo à tona um histórico da presença do tema nas constituições federais até a atual de 1988. A lém disso, enfatiza a necessidade de recorrer à justiça sempre que alguém sinta seu direito à liberdade de crença violado, ou seja, acaba por levantar a bandeira em defesa da liberdade de crença e de culto como um direito que deve ser assegurado a todo e qualquer cidadão, seja ele católico, espírita, evangélico ou adepto de alguma religião de matriz africana. Hédio, inclusive, mostra que já tem em seu histórico profissional como advogado a procedência de algumas ações impetradas na justiça em favor da garantia da liberdade religiosa de seus clientes, em sua maioria de afro-brasileiros que sofreram alguma restrição ou constrangimento vinculado à sua prática religiosa.

o livro, por fim, traz uma vasta reflexão sobre o papel atual dos neopentecostais no cenário religioso. Muito já se discutiu sobre os efeitos que suas ações vêm causando na sociedade brasileira. Se há uma estrutura e uma eficácia simbólica, como diz Silva em seu artigo, movendo o sucesso do empreendimento neopentecostal, isso sugere a importância dos trabalhos que envolvem a análise de seus cultos, de seu discurso, bem como da atuação de 
seus agentes na política e na mídia em geral. Esta coletânea recupera trabalhos importantes sobre a atuação da Igreja Universal do Reino de Deus e é leitura obrigatória para aqueles que de alguma forma se aventuram a estudar os efeitos causados pela religião no mundo moderno.

Janayna de Alencar Lui (janayna@ iser.org.br)

Mestre em A ntropologia Social pelo PPGAS/UFSC, Doutoranda em A ntropologia pelo PPGSA/IFCS/UFRJ e pesquisadora do ISER. 